\title{
Emerging prophylaxis strategies against COVID-19
}

\author{
Sumita Agrawal ${ }^{1}$, Akhil Dhanesh Goel ${ }^{2}$, Nitesh Gupta ${ }^{3}$ \\ ${ }^{1}$ Pulmonary Medicine and Critical Care, Medipulse Hospitals, Jodhpur; ${ }^{2}$ Community Medicine and Family Medicine, \\ All India Institute of Medical Sciences, Jodhpur; ${ }^{3}$ Department of Pulmonary Medicine and Critical Care and Nodal \\ Officer (Coronavirus Outbreak), Vardhaman Mahavir Medical College and Safdarjung Hospital, New Delhi, India
}

\section{To the Editor}

The Novel corona virus 2019 which started as an outbreak in China in December 2019 has rapidly spread all over the world, such that on $11^{\text {th }}$ March 2020 WHO declared this disease as pandemic $[1,2]$. The emergency that the world faces today demands that we develop urgent and effective measures to protect people at high risk of transmission. WHO has accelerated research in diagnostics, vaccines and therapeutics for this novel coronavirus [3].

The various strategies for prevention of transmission and infection of this respiratory pathogen includes:

1) Health promotion - non pharmacological interventions [4]:

a. isolation at home,

b. voluntary quarantine at home,

c. social distancing of entire population especially of the elderly and

d. temporary closure of schools, universities and work places.

2) Specific protection through chemoprophylaxis or immunoprophylaxis which includes:

Correspondence: Dr. Akhil Dhanesh Goel, C-214 CMFM, All India Institute of Medical Sciences, Basni-phase 2, Jodhpur 342005, Rajasthan, India.

E-mail: doc.akhilgoel.aiims@gmail.com

Keywords: Corona virus; chemoprophylaxis; immunoprophylaxis.

Authors' contribution: All the authors made substantial contributions to the conception/design of the work, acquisition, analysis, or interpretation of data, drafting the work or revising it critically for important intellectual content. All the authors have read and approved the final version of the manuscript and agreed to be accountable for all aspects of the work.

Conflict of interest: the Authors declare no conflict of interest.

Ethical approval: not applicable.

Received for publication: 27 March 2020.

Accepted for publication: 27 March 2020.

${ }^{\circ}$ Copyright: the Author(s), 2020

Licensee PAGEPress, Italy

Monaldi Archives for Chest Disease 2020; 90:1289

doi: 10.4081/monaldi.2020.1289

This article is distributed under the terms of the Creative Commons Attribution Noncommercial License (by-nc 4.0) which permits any noncommercial use, distribution, and reproduction in any medium, provided the original author(s) and source are credited.
1. Antiviral agents;

2. Chloroquine-HydroxyChloroquine (HCQS);

3. Vaccination.

This article is an overview of the emerging prophylaxis strategies under investigation against COVID-19.

\section{Antiviral agents}

Neuraminidase inhibitors are known to reduce viral shredding in respiratory secretions and is used for prophylaxis against influenza [5]. Jefferson et al. in a Cochrane systematic review found reduction in symptomatic influenza by $55 \%$ by Oseltamivir and $61 \%$ by Zanamavir [6]. Oseltamivir is currently being investigated as a treatment option (NCT04303299) but not specifically for prophylaxis against the corona virus disease. However, taking cue from its prophylaxis properties against influenza viruses, it may have a role in chemoprophylaxis in corona virus disease as well.

Protease inhibitors like Lopinavir have shown to be a strong inhibitor of the protease enzyme present in SARS-CoV which is important for the life cycle function of this virus [7]. Ritonavir has been used to boost this action of Lopinavir in HIV patients [8]. However, the largest study reported till date on use of Lopinavir plus Ritonavir for its efficacy in patients infected with COVID-19 conducted in China found no difference in the clinical outcome when compared to standard care alone [9].

There is currently a trial NCT04304053 ongoing to look into the efficacy of Darunavir/Cobicistat plus chloroquine treatment in all who are found to be infected. Currently, there is no recommendation for use of antiviral agents for prophylaxis of COVID-19.

\section{Chloroquine-HydroxyChloroquine Sulphate}

Chloroquine is a widely known for more than 70 years, is easily available and affordable antimalarial agent with proven chemoprophylaxis properties in malaria. Various mechanisms have shown it to have a role in SARS CoV infection, too. The SARS-CoV2 is known to bind to human cells via the Angiotensin Converting Enzyme 2 (ACE 2) receptor. In vitro studies have shown that the glycosylation process of ACE2 receptor gets affected thus causing the Vero cells pre-treated with chloroquine to be refractory to SARS-CoV infection, that may be the mechanism through which even human cells can become refractory to this infection [10]. It has also been seen that treatment with chloroquine prevents the spread of SARS-CoV infection in the postinfection period [11]. 
HCQS has the same mechanism of action but a better safety profile than chloroquine and hence makes it a more preferable drug. Both these drugs have also shown to have immunomodulatory effects and can suppress the increase immune factors [11], which may play a role in reducing the severity of coronavirus disease.

The first ever human trial of chloroquine against COVID-19 was conducted by Chinese investigators. The study conducted in more than 100 patients found chloroquine to be superior in reducing symptom duration, exacerbation of pneumonia, radiological improvement and lead to virus-negative seroconversion [12].
Hydroxychloroquine along with azithromycin was studied by the French group of investigators. It was an open label non-randomized control trial. They included 36 patients in the trial and 20 patients were given hydroxychloroquine at a dose of $600 \mathrm{mg}$ daily along with azithromycin. The authors showed significant reduction in viral load on day 6 of the treatment and much lower average carrying duration of the virus as compared to the control group [13]. Currently many trials are underway to study the effect both for prophylaxis and treatment (Table 1).

Based on these studies, the Indian Council of Medical

Table 1. Summary of ongoing clinical trials for chemoprophylaxis.

\begin{tabular}{|c|c|c|c|c|c|c|c|c|}
\hline Number & Title & Interventions & Age & Allocation & Masking & Start Date & $\begin{array}{l}\text { Expected } \\
\text { Completion } \\
\text { Date }\end{array}$ & Locations \\
\hline 1. NCT04304053 & $\begin{array}{l}\text { Treatment of } \\
\text { COVID-19 } \\
\text { Cases and } \\
\text { Chemoprophylaxis } \\
\text { of Contacts as } \\
\text { Prevention }\end{array}$ & $\begin{array}{l}\text { Antiviral } \\
\text { treatment } \\
\text { and prophylaxis } \\
\text { us Standard } \\
\text { Public Health } \\
\text { measures }\end{array}$ & $\geq 18$ years & Randomized & Open Label & March 18, 2020 & June 15,2020 & $\begin{array}{l}\text { Barcelona, } \\
\text { Spain }\end{array}$ \\
\hline 2. NCT04318444 & $\begin{array}{l}\text { Hydroxychloroquine } \\
\text { Post Exposure } \\
\text { Prophylaxis for } \\
\text { Coronavirus Disease } \\
\text { (COVID-19) }\end{array}$ & $\begin{array}{l}\text { Hydroxychloroquine } \\
\text { us Placebo }\end{array}$ & $\geq 18$ years & Randomized & $\begin{array}{l}\text { Quadruple } \\
\text { (Participant, } \\
\text { Care Provider, } \\
\text { Investigator, } \\
\text { Outcomes } \\
\text { Assessor) }\end{array}$ & Mar-20 & Mar-22 & $\begin{array}{l}\text { New York, } \\
\text { United } \\
\text { States }\end{array}$ \\
\hline 3. NCT04318015 & $\begin{array}{l}\text { Hydroxychloroquine } \\
\text { Chemoprophylaxis } \\
\text { in Healthcare } \\
\text { Personnel in Contact } \\
\text { With COVID-19 } \\
\text { Patients } \\
\text { (PHYDRA Trial) }\end{array}$ & $\begin{array}{l}\text { Hydroxychloroquine } \\
\text { us Placebo }\end{array}$ & $\geq 18$ years & Randomized & $\begin{array}{l}\text { Quadruple } \\
\text { (Participant, } \\
\text { Care Provider, } \\
\text { Investigator, } \\
\text { Outcomes } \\
\text { Assessor) }\end{array}$ & April 1, 2020 & March 31, 2021 & \\
\hline 4. NCT04251871 & $\begin{array}{l}\text { Treatment and } \\
\text { Prevention of } \\
\text { Traditional Chinese } \\
\text { Medicines (TCMs) } \\
\text { on 2019-nCoV } \\
\text { Infection }\end{array}$ & $\begin{array}{l}\text { Oxygen therapy, alfa } \\
\text { interferon via aerosol } \\
\text { inhalation, and } \\
\text { lopinavir/ritonavir } \\
\text { and Traditional } \\
\text { Chinese Medicines } \\
\text { (TCMs) granules }\end{array}$ & $\begin{array}{l}14 \text { Years to } \\
80 \text { Years }\end{array}$ & Randomized & Open Label & January 22, 2020 & January 22, 2021 & $\begin{array}{l}1 \text { Beijing, } \\
\text { China }\end{array}$ \\
\hline 5. NCT04303507 & $\begin{array}{l}\text { Chloroquine } \\
\text { Prevention of } \\
\text { Coronavirus Disease } \\
\text { (COVID-19) in the } \\
\text { Healthcare Setting }\end{array}$ & $\begin{array}{l}\text { Chloroquine } \\
\text { vs Placebo }\end{array}$ & $\geq 16$ years & Randomized & $\begin{array}{l}\text { Double } \\
\text { (Participant, } \\
\text { Investigator) }\end{array}$ & May-20 & May-22 & $\begin{array}{l}\text { Oxford, } \\
\text { United } \\
\text { Kingdom }\end{array}$ \\
\hline 6. NCT04321174 & $\begin{array}{l}\text { COVID-19 } \\
\text { Ring-based } \\
\text { Prevention } \\
\text { Trial With } \\
\text { Lopinavir/Ritonavir }\end{array}$ & $\begin{array}{l}\text { Drug: } \\
\text { Lopinavir/ritonavir }\end{array}$ & $\geq 18$ years & Randomized & $\begin{array}{l}\text { Masking: } \\
\text { Single } \\
\text { (Outcomes } \\
\text { Assessor) }\end{array}$ & March 30, 2020 & March 31, 2022 & $\begin{array}{l}\text { Ontario, } \\
\text { Canada }\end{array}$ \\
\hline 7. NCT04312243 & $\begin{array}{l}\text { NO Prevention of } \\
\text { COVID-19 for } \\
\text { Healthcare } \\
\text { Providers }\end{array}$ & $\begin{array}{l}\text { Drug: Inhaled nitric } \\
\text { oxide gas }\end{array}$ & $\begin{array}{l}18 \text { to } 99 \\
\text { Years }\end{array}$ & Non-Randomized & $\begin{array}{l}\text { Masking: None } \\
\text { (Open Label) }\end{array}$ & March 20, 2020 & March 20, 2022 & $\begin{array}{l}\text { Boston, } \\
\text { United } \\
\text { States }\end{array}$ \\
\hline 8. NCT04308668 & $\begin{array}{l}\text { Post-exposure } \\
\text { Prophylaxis for } \\
\text { SARS-Coronavirus-2 }\end{array}$ & $\begin{array}{l}\text { Hydroxychloroquine } \\
\text { us Placebo }\end{array}$ & $\geq 18$ years & Randomized & $\begin{array}{l}\text { Quadruple } \\
\text { (Participant, } \\
\text { Care Provider, } \\
\text { Investigator, } \\
\text { Outcomes } \\
\text { Assessor) }\end{array}$ & March 17, 2020 & May-21 & $\begin{array}{l}\text { Minnesota, } \\
\text { United } \\
\text { States }\end{array}$ \\
\hline
\end{tabular}


Table 2. Summary of ongoing clinical trials for immunoprophylaxis.

\begin{tabular}{|c|c|c|c|c|c|c|c|c|}
\hline Number & Title & Interventions & Age & $\begin{array}{l}\text { Intervention } \\
\text { model }\end{array}$ & Masking & Start date & $\begin{array}{l}\text { Completion } \\
\text { date }\end{array}$ & Locations \\
\hline 1. NCT04299724 & $\begin{array}{l}\text { Safety and Immunity } \\
\text { of Covid-19 aAPC } \\
\text { vaccine }\end{array}$ & $\begin{array}{l}\text { Biological: } \\
\text { pathogen-specific } \\
\text { aAPC }\end{array}$ & $\begin{array}{l}6 \text { months } \\
\text { to } 80 \text { years }\end{array}$ & $\begin{array}{l}\text { Single arm } \\
\text { clinical trial }\end{array}$ & Open label & $\begin{array}{l}\text { February 15, } \\
2020\end{array}$ & $\begin{array}{l}\text { December } 31 \text {, } \\
2024\end{array}$ & $\begin{array}{l}\text { Guangdong, } \\
\text { China }\end{array}$ \\
\hline 2. NCT04276896 & $\begin{array}{l}\text { Immunity and safety } \\
\text { of Covid-19 synthetic } \\
\text { minigene vaccine }\end{array}$ & $\begin{array}{l}\text { Biological: injection } \\
\text { and infusion of } \\
\text { LV-SMENP-DC vaccine } \\
\text { and antigen-specific } \\
\text { CTLs }\end{array}$ & $\begin{array}{l}6 \text { months to } \\
80 \text { years }\end{array}$ & $\begin{array}{l}\text { Single arm } \\
\text { clinical } \\
\text { trial }\end{array}$ & Open label & March 24, 2020 & $\begin{array}{l}\text { December } 31 \text {, } \\
2024\end{array}$ & $\begin{array}{l}\text { Guangdong, } \\
\text { China }\end{array}$ \\
\hline 3. NCT04283461 & $\begin{array}{l}\text { Safety and } \\
\text { immunogenicity } \\
\text { study of 2019-nCoV } \\
\text { vaccine (mRNA-1273) } \\
\text { to prevent } \\
\text { SARS-CoV-2 infection }\end{array}$ & Biological: mRNA-1273 & $\begin{array}{l}18 \text { years to } \\
55 \text { years }\end{array}$ & $\begin{array}{l}\text { Non-randomized } \\
\text { trial }\end{array}$ & Open label & March 3, 2020 & June 1, 2021 & $\begin{array}{l}\text { United } \\
\text { States }\end{array}$ \\
\hline $\begin{array}{l}\text { 4. ChiCTR20000 } \\
30906\end{array}$ & $\begin{array}{l}\text { A phase I clinical trial } \\
\text { for recombinant } \\
\text { novel coronavirus } \\
\text { (2019-COV) vaccine } \\
\text { (adenoviral vector) }\end{array}$ & $\begin{array}{l}\text { Recombinant novel } \\
\text { coronavirus vaccine } \\
\text { (adenoviral vector) }\end{array}$ & $\begin{array}{l}18 \text { and } 60 \\
\text { years }\end{array}$ & $\begin{array}{l}\text { Non-randomized } \\
\text { trial }\end{array}$ & Open label & March 16, 2020 & $\begin{array}{l}\text { December } 31 \text {, } \\
2020\end{array}$ & $\begin{array}{l}\text { Hubei, } \\
\text { China }\end{array}$ \\
\hline
\end{tabular}

Research (ICMR) [14] has recommended the use of HCQS for prophylaxis of:

- All health care workers those who are involved in the care of suspected or confirmed cases of COVID-19: $400 \mathrm{mg}$ twice a day on day 1 , followed by $400 \mathrm{mg}$ once weekly for next 7 weeks; to be taken with meals.

- Asymptomatic household contacts of laboratory confirmed cases may be prescribed $400 \mathrm{mg}$ twice a day on day 1 , followed by $400 \mathrm{mg}$ once weekly for next 3 weeks; to be taken with meals.

Currently, clinical guidance on the use, dosing, or duration of hydroxychloroquine for prophylaxis or treatment of SARS-CoV-2 infection is lacking from CDC due to absence of randomized clinical trials (RCTs).

Similarly, JHMI clinical guidance do not recommend pre or post exposure prophylaxis in individuals with suspected exposure to SARS-CoV-2 [15].

\section{Precautions}

Patients taking these drugs should be frequently monitored for hematological parameters, serum electrolytes, blood glucose, hepatic and renal functions. As these drugs are known to cause QTc prolongation, routine ECG is essential prior to starting these drugs. Co-administration of other drugs known to cause QTc prolongation should be avoided.

\section{Vaccines}

There is considerable global investment and effort towards development of a vaccine (Table 2). The US (NIAID) collaborated with Moderna to develop an RNA vaccine. A safety clinical trial of the candidate vaccine mRNA-1273 is underway with sample size of 45 volunteers [16]. Another, Phase I safety trial of a recombinant adenovirus vaccine candidate (CanSino Biologics Inc.
(Tianjin, China)), Ad5-nCoV, recruiting 108 healthy adults in Wuhan, China in March [17]. However, a possible vaccine in development may or may not be safe or effective in future.

We hope that the results of the ongoing trials give us more insight on prophylaxis and help in better prevention and thus decreasing the transmission of this widely spreading disease.

\section{References}

1. WHO. WHO Director-General's opening remarks at the media briefing on COVID-19 - 11 March 2020. Accessed on: 24 March 2020. Available from: https:/www.who.int/dg/speeches/detail/who-director-general-s-opening-remarks-at-themedia-briefing-on-covid-19-11-march-2020

2. Guan W, Ni Z, Hu Y, et al. Clinical characteristics of coronavirus disease 2019 in China. N Engl J Med 2020. doi: 10.1056/NEJMoa2002032.

3. Mitjà $\mathrm{O}$, Clotet $\mathrm{B}$. Use of antiviral drugs to reduce COVID-19 transmission. Lancet Glob Heal 2020. pii: S2214109X(20)30114-5. doi: 10.1016/S2214-109X(20)30114-5. [Epub ahead of print].

4. Ferguson NM, Laydon D, Nedjati-Gilani G,et al. Impact of non-pharmaceutical interventions (NPIs) to reduce COVID-19 mortality and healthcare demand. Imperial College COVID-19 Response Team. doi: 10.25561/77482

5. Welliver R, Monto AS, Carewicz O, et al. Effectiveness of oseltamivir in preventing influenza in household contacts: A randomized controlled trial. J Am Med Ass 2001;285:748-54.

6. Dayer MR, Taleb-Gassabi S, Dayer MS. Lopinavir; a potent drug against coronavirus infection: Insight from molecular docking study. Arch Clin Infect Dis 2017;12:e13823.

7. Oldfield V, Plosker GL. Lopinavir/ritonavir: A review of its use in the management of HIV infection. Drugs 2006;66: 1275-99.

8. Cao B, Wang Y, Wen D, et al. A trial of lopinavir-ritonavir in 
adults hospitalized with severe Covid-19. N Engl J Med 2020. doi: 10.1056/NEJMoa2001282

9. Vincent MJ, Bergeron E, Benjannet S, et al. Chloroquine is a potent inhibitor of SARS coronavirus infection and spread. Virol J 2005;2:69.

10. Savarino A, Boelaert JR, Cassone A, et al. Effects of chloroquine on viral infections: An old drug against today's diseases? Lancet Infect Dis 2003;3:722-7.

11. Yao X, Ye F, Zhang M, et al. In vitro antiviral activity and projection of optimized dosing design of hydroxychloroquine for the treatment of severe acute respiratory syndrome Coronavirus 2 (SARS-CoV-2). Clin Infect Dis 2020.pii: ciaa237. doi: 10.1093/cid/ciaa237. [Epub ahead of print].

12. Gao J, Tian Z, Yang X. Breakthrough: Chloroquine phosphate has shown apparent efficacy in treatment of COVID-19 associated pneumonia in clinical studies. Biosci Trends 2020;14:72-3.

13. Gautret P, Lagier J-C, Parola P, et al. Hydroxychloroquine and azithromycin as a treatment of COVID-19: results of an openlabel non-randomized clinical trial. Int J Antimicrob Agents 2020; 105949. doi: 10.1016/j.ijantimicag.2020.105949. [Epub ahead of print]
14. Indian Council of Medical Research [Internet]. Advisoryon the use of Hydroxychloroquin as prophylaxis for SARSCoV2 infection. Accessed on: 24 March 2020. Available from: https:/www.mohfw.gov.in/pdf/AdvisoryontheuseofHydroxy chloroquinasprophylaxisforSARSCoV2infection.pdf

15. Writing Group of the Johns Hopkins University and Johns Hopkins Hospital COVID-19 Treatment Guidance Working Group [Internet]. JHMI Clinical Guidance for Available Pharmacologic Therapies for COVID-19. Available from: https://www.hopkinsguides.com/hopkins/ub?cmd=repview\&t ype $=479-1112$ \&name $=3$ 538747_PDF

16. Kaiser Permanente Washington Health Research Institute [Internet]. Kaiser Permanente launches first coronavirus vaccine trial. Kaiser Permanente, Washington Health Research Institute, Seattle, 16 March 2020. Retrieved: 23 March 2020.

17. Bloomberg News [Internet]. Chinese vaccine approved for human testing at virus epicentre, 17 March 2020. Retrieved: 24 March 2020. Available from: https://www.bloomberg.com/ news/articles/2020-03-18/chinese-vaccine-approved-forhuman-testing-at-virus-epicenter 